\title{
Local Knowledge on the Influence of Land Use/Cover Changes and Conservation Threats on Avian Community in the Kilombero Wetlands, Tanzania
}

\author{
Wilbard A. Ntongani ${ }^{*}$, Pantaleo K. T. Munishi' ${ }^{1}$, Stein R. More' ${ }^{2}$, Japhet J. Kashaigili ${ }^{3}$ \\ ${ }^{1}$ Department of Forest Biology, Sokoine University of Agriculture, Morogoro, Tanzania \\ ${ }^{2}$ Department of Ecology and Natural Resource Management, University of Life Sciences, Ås, Norway \\ ${ }^{3}$ Department of Forest Mensuration and Management, Sokoine University of Agriculture, Morogoro, Tanzania \\ Email: ${ }^{\text {ntongani@gmail.com }}$
}

Received 4 June 2014; revised 14 July 2014; accepted 10 August 2014

Copyright (C) 2014 by authors and Scientific Research Publishing Inc.

This work is licensed under the Creative Commons Attribution International License (CC BY). http://creativecommons.org/licenses/by/4.0/

(c) (†) Open Access

\begin{abstract}
Local knowledge of the history and ecology of wetland ecosystems is very useful in wetland resources management, especially when other historical ecological information is not available and can be integrated with scientific knowledge to introduce better management of resources. The aims of this paper were to assess existing local knowledge on land use/cover changes in the Kilombero wetlands, thereafter investigate local knowledge on its effect on avian population in the wetland and identify factors influencing local knowledge on such changes in the study area. Random sampling was used to obtain representative sample population for this study. Structured questionnaire and focus group discussions were used to extract information from local people in six villages. Study results from multi-response analysis showed that natural forests had been converted into cropland and bushed grassland, grassland to crop land, grassland to grazed land, forest to settlement and grassland to settlement. Land use change was singled out as primary cause of decrease in avian community in the wetland. Threats to the conservation of avian species were identified as livestock grazing, drought, use of poison, traps and bush meat hunting for food. Age and education level were seen as determinants of household's knowledge on the ecological changes. This pool of existing knowledge is important among wetland users and stakeholders in order to generate conservation strategies of the wetland ecosystem.
\end{abstract}

\section{Keywords}

Local Knowledge, Wetland, Land Use, Avian, Conservation

\footnotetext{
${ }^{*}$ Corresponding author.
}

How to cite this paper: Ntongani, W.A., Munishi, P.K.T., More, S.R. and Kashaigili, J.J. (2014) Local Knowledge on the Influence of Land Use/Cover Changes and Conservation Threats on Avian Community in the Kilombero Wetlands, Tanzania. Open Journal of Ecology, 4, 723-731. http://dx.doi.org/10.4236/oje.2014.412062 


\section{Introduction}

Wetlands are converted to other land uses due to agriculture and livestock grazing in many parts of the world [1]-[4] and such human activities affect avian abundance and diversity in the grassland and wetland habitats [5]-[7]. This may be due to services and benefits that are associated with the presence of the wetlands, like fertile soils, water throughout the year which attracts human population to settle and introduce several activities in and around these wetlands.

Local knowledge of the history and ecology of wetland ecosystems is useful in wetland resources management. Historical information can be integrated with scientific knowledge to introduce better management options of natural resources [8]-[10]. Local knowledge has been used to identify conservation threats to the mangrove forests [10]. Apart from being source of ecological information of a given landscape, local knowledge facilitates community to participate in the environmental management. Furthermore, gathering ecological information, oral history also paves the way toward of sustainable resource management by enabling the values and concerns of local community and stakeholders to be articulated, and thus increasing managers' understanding of the social context of the particular locality, which is fundamental to sound environmental decision making and implementation [9] [11] [12]. It is generally accepted that community involvement in understanding local resources increases the possibilities of management actions. For example, local knowledge has been used in monitoring water quality and grazing landscapes to understand how ecological changes happened on such landscapes over time and space [13].

Local ecological knowledge is the knowledge of a particular group of people about local ecosystems, and in contrast to traditional ecological knowledge, does not assume a continuous historical and cultural connection with the ecosystem [14]. Local ecological knowledge can be gathered by using questionnaires [15], by investigating the written documents and maps [9], and through oral history [16]. Oral history is obtained through a prepared dialogue between two persons. Interviewer determines information needed to grasp the ecological knowledge in focus [17].

Several studies have reported the values of oral history as a means to incorporate local ecological knowledge in ecosystem management [9] [10]. For instance, hunters' knowledge has been used to study sustainability of hunting practices on non-game bird species. They were able to suggest specific management actions to reduce the impacts on threatened non-game species in Mexico and United States of America [11]. On the other hand, herders' knowledge has been used to study ecological dynamics of landscapes in northern Tanzania and effects of livestock grazing across seasonal grazing landscapes were evaluated through herder perceptions and field data on plant species composition, richness, biomass and cover [13]. Furthermore, local perceptions on seasonal wetland landscape variability had shown that communities within the Rufiji Delta Tanzania were knowledgeable about the usefulness of such variability [18]. River flooding was viewed as an important factor for soil fertility and crop yield in the Rufiji Delta. Therefore, the specific goals of this study were: firstly, to assess local knowledge on land use/cover changes in the Kilombero wetlands; and secondly, to investigate local knowledge on trend of avian community in the Kilombero wetlands and find out factors determining local knowledge on land use change and avian species in the wetland.

\section{Study Site}

The study was conducted in the Kilombero Valley Floodplain a Ramsar site since $25^{\text {th }}$ April, 2002 [19]. The wetland is 796,735 ha located $8^{\circ} 40^{\prime} \mathrm{S}$ and $36^{\circ} 10^{\prime} \mathrm{E}$ in Morogoro region, Tanzania. The floodplain forms part of Selous Game Reserve, recognized by United Nations Educational, Scientific and Cultural Organization as the World Heritage ecosystem and also the International Union for Conservation of Nature (IUCN) renowned largest wetland valley in Africa. It floods during the rainy season and as days approaches the dry season the larger part of the floodplain dries including few river streams from mountain areas. Kilombero valley floodplain has the advantage of collecting water from its diverse catchment area through small rivers flowing into this valley during wet and dry seasons. This catchment includes Udzungwa and Mahenge mountains and extends from mountain ranges of Iringa and Mbeya regions [20].

The river streams within the extensive floodplain converge near Ifakara to about four kilometres wide near Kivukoni by forming the main stream known as the Kilombero river. From Kivukoni near Ifakara town, the main river flows to north-east about 65 kilometers until it enters into the Selous Game Reserve which is the border of the Kilombero ramsar site. The area receives rainfall between 1200 to $1400 \mathrm{~mm}$ annually and $17^{\circ} \mathrm{C}$ to 
$24^{\circ} \mathrm{C}$ annual temperature.

The vegetation cover categories of the study area is associated with the nature of the floodplain, where the vegetation is distinguished as the distance increases from the main stream of the river flow towards the mountains bordering the wetland, Udzungwa and Mahenge mountain ranges [20]. Its vegetation categories range from tall and short grass, woodlands to forests. Forest habitats are found on large part of Ulanga district for instance Nambinga forest and some forest patches in the Kibasira Swamp in Kilombero district [20] [21]. The wetland is very rich in wildlife; it hosts rare and common species which are ecologically classified as either endemic, vulnerable or endangered. Threatened species include animal species like blue duiker, cheetah, lion and birds like Kilombero Weaver (Ploceus burnieri), Stierling's woodpecker (Dendropicos stierlingi), Southern-banded snake eagle (Circaetus fasciolatus) others as are shown in the IUCN red list.

The study area has experienced human population increase over thirty years as was indicated in population and housing census reports of 1978, 1988 and 2002, with a population of nine persons per square kilometre, which has more implications on the resource use in the wetlands.

\section{Methodology}

Literature reviews and field techniques were used to collect information for this study. At the beginning, household heads for every village were listed and stratified into two portions based on gender. The names of household heads were used as sampling frame and the household was considered as an important unit of analysis where the right data could be extracted [22] because households are users of local natural resources within the wetland and could notice any changes happening around them over time. Names of households were obtained from sampled village registers. This technique helped to identify and differentiate female and male headed households in the study area in order to get fair gender representation during the questionnaire administration and focus group discussion. Random sampling of 35 households were picked from stratified data of every studied village.

It is recommended that thirty respondents in a sampled population constitute a realistic sample size for field work data collection and analysis [23] [24]. Investigations on socio-economic studies in Sub-Saharan Africa require a sample size between 80 to 120 household respondents [15] [25]. For the purpose of this study a total of 210 respondents were sampled from six villages for interview. Therefore, without considering the total number of household that was found in every village which was sampled, the population sample size was considered as sufficient to generate statistical inferences required for making study conclusions.

Focus group discussions were conducted in order to supplement information that was obtained from questionnaire investigation. The selection of focus group discussion participants was based on two criteria, first, a participant had to be a village resident with a long and sufficient knowledge of the village history aged above fifty years and secondly, he or she had to be considered to understand well the local natural resources available in the village [15] [25]. The village executive officer and Chairman for each village involved were consulted to initiate to obtain members of the group. At least three individuals were selected using village leaders knowledge and thereafter, the proposed individuals were used to include other members whom they thought had enough knowledge to participate in the exercise. The minimum of 4 men and 4 women were allowed to participate in each village. Thus 48 persons were involved in focus group discussions throughout the studied villages. Males and females formed their two independent group discussions. This procedure had an advantage of allowing more freedom especially women to air their opinions and views very openly on the matters of socio-economic activities that had happen in the valley and their impacts on land use and cover change and how they perceive effect of changes of native habitats to bird diversity in the wetland.

Both quantitative and qualitative data were analysed during this study. The quantitative data that were obtained through the household questionnaire survey including answers from open ended questions were coded and entered into the statistical software (STATA 9) for analysis. The results were summarised and presented into percentages, tabular form and figures. The analysis was very useful to determine the extent of knowledge of local people for changes which happened in their environment and possible reasons for such changes. On the other hand, the collected qualitative information was analysed depending on its source [26]. For example, the information collected through focus group discussion was sorted and labeled to enable meaningful analysis and interpretation. Therefore, the content functional analysis was performed for the analysis of such data. This analysis helps to know the attitudes of the interviewed person [22] which show the actual feeling of the respondent to- 
wards the ideal argument raised within the discussion. The views obtained using this technique helped to know more significant causes of land use/cover change and effects on bird diversity as recognized by local people. It helped to relate the changing habitat in people's environment with actual evidence as understood from local people in the wetland. Thus, a multiple response analysis was used to identify peoples' knowledge on land use change, causes and conservation threats in the study area. The chi-square was used to identify effects of age and education level on the local knowledge of land use change and avian community in the wetland. Furthermore, every household interviewed was given an opportunity to look at photographs of common avian species found in the wetland using the field guide for species identification using the local knowledge.

\section{Results}

\subsection{Local Knowledge on Land Use/Cover Change}

The field survey results indicated that local people had witnessed various land use/cover transformation during their lifetime. The majority acknowledged to have noted land use/cover changes in the wetland, For example $85 \%$ of interviewed households said natural forests to have been converted into cropland, although could not classify which category of forest (closed or open forest or, wooded grassland or woodland) but they were referring to areas which had thick trees in the past and now have been turned into cultivated areas.

For the period of more than thirty years, the cultivated land has always increasing when compared to other land use categories. However the areas of urban settlements have increased especially Ifakara and Mlimba centres, other areas like Chita, Mngeta, Mbingu and Idete for side of Kilombero district while Kivukoni, Lupiro, Mtimbira and Malinyi on the part of Ulanga district are among of settlement centres which are growing very fast attracting population and are acting as trading centres in the wetlands.

The findings (68\%) from local people views showed that human settlements have increased towards natural habitats since 1970s to 2000s. The mode of cultivation would have caused the need of extensive land use since the most of households did not acknowledge to have used modern methods of agricultural farming including use of fertilizers and proper space crop planting in order to have enough crop harvest per hectare. The low harvest per hectare would attract demand of more land for clear cut and burn for farm expansion, the practice which have resulted into land use/cover change in the study area.

\subsection{Local Knowledge on Root Causes of Land Use/Cover Change in the Wetland}

Local peoples understanding of the main reasons for land use change indicate that livestock keeping rank first (88\%), followed by agricultural activities (84\%), settlement (77\%), bush fires (73\%), charcoal making (40\%), fuel wood collection (35\%) and tree felling for timber and poles (31\%). The field observation indicated that areas which are occupied of pastoralists, the closed and open vegetated areas are highly affected during the dry season since these pastoralists graze their livestock in these areas because they contain water and vegetation diet for livestock resulting into completely change of affected habitat within the ecosystem. Studies which have been done in the wetland they mentioned on the conservation threats existing in the wetland but did not show the extent of changes that have happened over a certain period by actual quantification of areas.

\subsection{Local Knowledge on the Avian Populations in the Wetland}

Local people showed great interest on species identification during field interview and discussions. Thirty three species (Table 1) were identified successfully using local knowledge. Every interviewed person mentioned at least one species. Most of these species were those which are very common in the wetland and can visually be found easily.

\subsection{Local Knowledge on Conservation Threats to the Avian Community in the Wetland}

From the interviews, local people were very much concerned about the future abundance of avian species in the wetland. About $87 \%$ of all persons who were interviewed gave their opinions that continuation of extensive agricultural activities into the interior of the wetland is increasing pressure on the existing ecosystem and avian species as among of ecosystem beneficiaries will continue to suffer except those which do not need special habitats. 
Table 1. Avian species identified using local knowledge in the wetland.

\begin{tabular}{|c|c|c|}
\hline Scientific name & English name & Local name \\
\hline Haliaeetus vocifer & African Fish Eagle & Ngwasi \\
\hline Treron calva & African Green-Pigeon & Ninga \\
\hline Anastomus lamelligerus & African Open-Billed Stork & Kopo la ngongo \\
\hline Tchagra senegala & Black-Crowned Tchagra & Kalitwika \\
\hline Lonchura cuculata & Bronze Mannikin & Mtundu \\
\hline Dendropicos fuscescens & Cardinal Woodpeker & Ng'ong'ondo \\
\hline Bubulcus ibis & Cattle Egret & Ndandala \\
\hline Pycnonotus barbatus & Common Bulbul & Likongojole \\
\hline Francolinus sephaena & Crested Francolin & Ngwale \\
\hline Alopochen aegyptiacus & Nightjar & Chaluwatula \\
\hline Anthus cinnamomeus & Grassland Pipit & Kipulima \\
\hline Pelecanus onocrotalus & Great White Pelican & Mbinji \\
\hline Scopus umbretta & Hamerkop & Mgetu \\
\hline Numida meleagris & Helmeted Guineafoul & Ng'ang'a \\
\hline Ploceus burnieri & Kilombero Weaver & Mbalamatete \\
\hline Phalacrocorax africanus & Long-Tailed Cormorant & Ndukunduku \\
\hline Lophaetus occipitalis & Long-Crested Eagle & Kipanga \\
\hline Leptoptilos crumeniferus & Marabou Stork & Twangu \\
\hline Gypohierax angolensis & Palm-Nut Vulture & Ngwasi \\
\hline Ceryle rudis & Pied Kingfisher & Chamlopo \\
\hline Ardea purpurea & Purple Heron & Limdede \\
\hline Quelea erythrops & Red-Headed Quelea & Kwelekwele \\
\hline Lagonosticta senegala & Red-Billed Firefinch & Kamtundu \\
\hline Francolinus afer & Red-Necked Spurfowl & Ng'wale \\
\hline Streptopelia capicola & Ring-Necked Dove & Kiiba \\
\hline Colius striatus & Speckled Mousebird & Simbilisi \\
\hline Bucorvus cafer & Southern Ground Hornbill & Nditi \\
\hline Plectropterus gambensis & Spur-Winged Goose & Miyogi \\
\hline Centropus superciliosus & White-Browed Coucal & Dudumizi \\
\hline Vanellus albiceps & White-Crowned Lapwing & Kolekole \\
\hline Ciconia ciconia & White Stork & Nyombi \\
\hline Euplectes nigroventris & Zanzibar Red Bishop & Ndagala \\
\hline Amandava subflava & Zebra Waxbill & Kalusambi \\
\hline
\end{tabular}

The livestock grazing (60\%) (Figure 1) and the unpredictable rainfall which have resulted into longer periods of drought season (18\%) in recent years provide another threat to the conservation of the species. Furthermore, the use of poison (16.19\%) and bush meat hunting (1.43\%) were seen as causing risks of species' survival in the wetland.

\subsection{Local Knowledge on Species Disappearing in the Wetland}

Local people used their local knowledge experience to single out kind of species which they see, they have a decreasing trend in the wetland when the occurrence of species at the time of fieldwork is compared to the past 


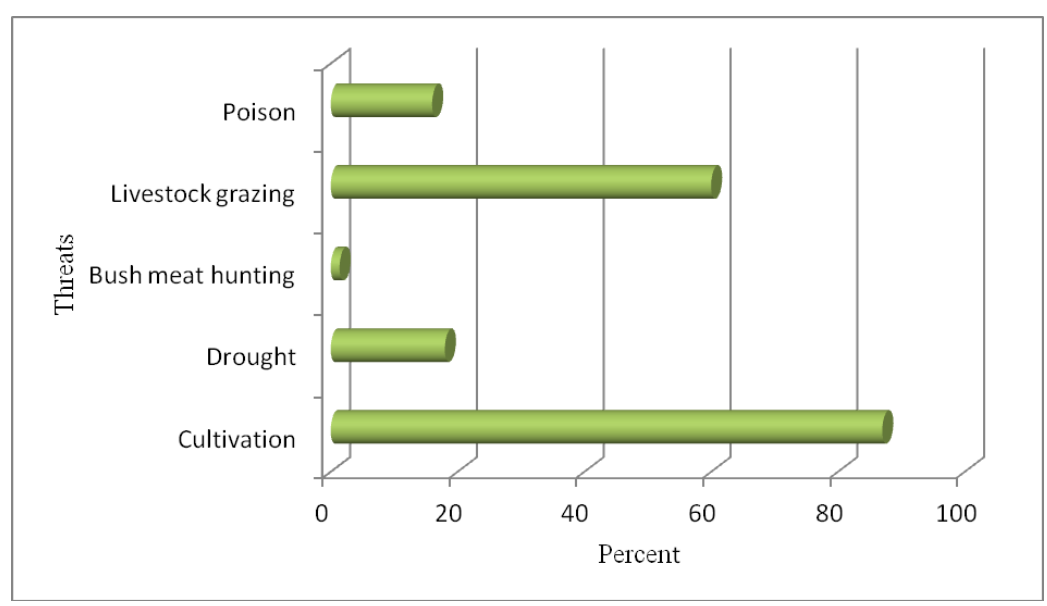

Figure 1. Conservation threats in Kilombero Wetland.

15 years, in the wetland.

The understanding of the decreasing species in the wetland as indicated in Table 2 was influenced by age of household head interviewed. The higher age and education level led to an increased awareness of changes of avian populations in the wetland. Both age and education level were statistically significant $(n=210, P<0.05)$. Species that were highly identified with decreasing trend included the Francolinus sephaena (Crested Flancolin), Numida meleagris (Helmeted Guineafoul), Francolinus afer (Red-necked Spurfowl) and Treron calvus (African Green-Pigion).

\section{Discussion}

This study has revealed that local knowledge about ecological changes is highly enhanced by age and the level of education. This observation concur with previous studies on local knowledge and biodiversity changes [1] [15] [27]-[29]. A person who has lived in the same environment with at least an age of 40 years and above was considered to have better knowledge of ecological changes that occurred in the past. This age corresponds to about two generations of population. Human increase from one generation to another with coupled human activities could lead to habitat changes as well as biodiversity in an environmental setting. This study got more useful information from aged household heads during group discussions. There were areas which had intact forests for instance from Namwai Forest to Mofu village and in the western part of Mofu Village. These areas, in 1970s, an individual person could not walk alone in these areas without accompanied by another person. In those days every one could fear to see the wildlife, but know is different. The forests have "changed completely to open woodland" one of interviewed household at Mofu village commented (pers.com.).

Through this study, regardless of education level of interviewed person, most of local people interviewed were able to distinguish land use/cover changes which happened for the past thirty years' time. They used their daily life experience to tell changes which they had observed in the past and showed possible threats to bird species. Some species' abundance showed a decline trend according to the local knowledge. Basing on their view, some human practices are strange to the species. The most activities which were unhappily said were the frequent occurrence of fire in wetland and use of traps and poison to kill bird species. The reasons for trapping and poisoning were mainly two; to obtain bush meat for food, most of target species are Guinea fowls and Francolins although other species are also trapped and eaten by humans. Hunting of avian species has been observed in other countries [11].

Poison was said to be used purposely to kill birds which are the pests to the food crop. It is a seasonal practice used by few farmers of paddy before harvest. The use of poison in wetlands is also reported in Kenya and Botswana as threat to bird species where Wood sandpiper (Tringa glareola) in Kenya around Bunyala paddy scheme were poisoned and sold for meat [30]. Furthermore, influx of large numbers of livestock since 1990s is another threat which was viewed by local people as one of challenge to the conservation of wetland habitats. Livestock keepers were associated with encroachment of green vegetated areas during the dry season. The fieldwork confirmed local observations on the existence of livestock in parts of Kibasira Swamp during the dry season 
Table 2. Descreasing bird species in the wetland.

\begin{tabular}{|c|c|c|c|}
\hline Scientific name & Species common name & Response $\left(\mathrm{N}^{1}=210\right) \mathrm{n}^{2}$ & Percent \\
\hline Serinus citrinelloides & African Citril & 5 & 2.38 \\
\hline Microcarbo africanus & Long-Tailed Cormorant & 30 & 14.29 \\
\hline Ardea purpurea & Purple Heron & 15 & 7.14 \\
\hline Francolinus afer & Red-Necked Spurfowl & 54 & 25.71 \\
\hline Ploceus burnieri & Kilombero Weaver & 7 & 3.33 \\
\hline Treron calvus & African Green Pigion & 40 & 19.05 \\
\hline Alopochen aegyptiacus & Egyptian Goose & 13 & 6.19 \\
\hline Numida meleagris & Helmeted Guineafowl & 74 & 35.24 \\
\hline Quelea erythrops & Red Headed Quelea & 3 & 1.43 \\
\hline Francolinus sephaena & Crested Francolin & 103 & 49.05 \\
\hline Strix woodfordii & African Wood Owl & 26 & 12.38 \\
\hline
\end{tabular}

${ }^{1}$ Entire sample count/respondents; ${ }^{2}$ Affirmative count/respondents to a particular question.

October, 2010. Such livestock disturbance in the wetland could have altered avian species composition, abundance and diversity in the wetland. This observation using local knowledge and field work is supported by other scholars who found that the intensive livestock grazing decreased avian abundance and diversity in the grassland and wetland habitats [5]-[7]. The abundance and diversity of species would depend on the habitat management and condition which determine the foraging status, breeding and nesting success of species.

\section{Conclusion}

This study has indicated that local knowledge is important in understanding the ecological changes that could have happened in the past and can be linked with the actual ecological information obtained through physical inventory or imagery acquired data for better understanding of changes in the wetland. The findings of this study can be used by decision makers in the process of wetland conservation. Local communities, stakeholders or wetland users should be well informed on changes happening in the wetland. These are the people who can be involved when conservation plans and strategies are to be addressed before their implementation. They can be informed about the effects of their daily human activities to the natural resources and be involved in setting out the conservation programs and laws at their local level to facilitate people understand and participate fully in the whole process of bylaw making for governing the biodiversity within the wetland. For that matter apart from bylaws, people residing in the wetland should be informed appropriate technologies on how they would change the mode of resource utilization within the wetland in order to reduce human pressure of resource use on the natural habitats.

\section{Acknowledgements}

This study was sponsored by the Norwegian Programme for Development, Research and Education (NUFU) program through the project NUFU-TZ 2007/10229, Integrating Livelihoods and Multiple Biodiversity Values in Wetlands Management in Tanzania. Sokoine University of Agriculture is thanked for providing research permit and field logistics. Thanks go to all people in the study area especially households whom without tireless used their time during interview and focus group discussions to provide valuable information for this study.

\section{References}

[1] Kangalawe, R., Mwakalila, S. and Masolwa, P. (2011) Climate Change Impacts, Local Knowledge and Coping Strategies in the Great Ruaha River Catchment Area. Tanzania Natural Resources, 2, 212-223. http://dx.doi.org/10.4236/nr.2011.24027

[2] Kovacs, J.M. (2000) Perceptions of Environmental Change in a Tropical Coastal Wetland. Land Degradation and Development, 11, 209-220. http://dx.doi.org/10.1002/1099-145X(200005/06)11:3<209::AID-LDR378>3.0.CO;2-Y

[3] Shemdoe, R.S., Kingazi, S.P., Kitula, R. and Chaggu E.J. (2007) Reducing Stress on Wetland Resources in Dryland 
Ecosystems of Mpwapwa District, Central Tanzania: Where Do We Start? Journal of Sustainable Development in Africa, 9, 197-206.

[4] Ambastha, K., Hussain, A.S. and Badola, R. (2007) Resource Dependence and Attitudes of Local People toward Conservation of Karbartal Wetland: A Case Study from the Indo-Gangetic Plains. Wetland Ecology Management, 15, 287302. http://dx.doi.org/10.1007/s11273-006-9029-z

[5] Gjersing, F.M. (1975) Waterfowl Production in Relation to Rest-Rotation Grazing. Journal of Range Management, 28, 37-42. http://dx.doi.org/10.2307/3897576

[6] Bowen, B.S. and Hamerlinck, O. (1993) Effects of Grazing on Nesting by Upland Sandpipiers in South Central North Dakota. Journal of Wildlife Management, 57, 291-301. http://dx.doi.org/10.2307/3809426

[7] Fondell, T.F. and Ball, J.J. (2004) Density and Success of Bird Nests Relative to Grazing on Western Montana Grasslands. Biological Conservation, 117, 203-221. http://dx.doi.org/10.1016/S0006-3207(03)00293-3

[8] Raban, C. (1996) Human Perceptions of Environmental Degradation in Part of the Kalahari Ecosystem. GeoJournal, 39, 65-67.

[9] Robertson, A.H. and Tara, K.M. (2003) Applying Local Knowledge: The Contribution of Oral History to Wetland Rehabilitation at Kanyapella Basin. Australia Journal of Environmental Management, 69, 275-228. http://dx.doi.org/10.1016/S0301-4797(03)00155-5

[10] Stringer, L.C. and Reed, M.S. (2007) Land Degradation Assessment in Southern Africa: Integrating Local and Scientific Knowledge Bases. Land Degradation and Development, 18, 99-116. http://dx.doi.org/10.1002/ldr.760

[11] Taylor, R.V. and Albert, S.K. (1999) Human Hunting of Non-Game Birds at Zuni, New Mexico, USA. Conservation Biology, 13, 1398-1403. http://dx.doi.org/10.1046/j.1523-1739.1999.98361.x

[12] Johnson, A. and Walker, D. (2000) Science, Communication and Stakeholder Participation for Integrated Natural Resource Management. Australian Journal of Environmental Management, 7, 82-90. http://dx.doi.org/10.1080/14486563.2000.10648488

[13] Oba, G. and Kaitira, L.M. (2006) Herder Knowledge of Landscape Assessments in Arid Rangelands in Northern Tanzania. Journal of Arid Environments, 66, 168-186. http://dx.doi.org/10.1016/j.jaridenv.2005.10.020

[14] Olsson, P. and Folke, C. (2001) Local Ecological Knowledge and Institutional Dynamics for Ecosystem Management: A Study of Lake Racken Watershed, Sweden. Ecosystems, 4, 85-104. http://dx.doi.org/10.1007/s100210000061

[15] Jew, E. and Bonnington, C. (2011) Socio-Demographic Factors Influence the Altitude of Local Residents towards Trophy Hunting Activities in the Kilombero Valley, Tanzania. African Journal of Ecology, 49, 277-285. http://dx.doi.org/10.1111/j.1365-2028.2011.01260.x

[16] Egan, D. and Howell, E.A. (2001) The Historical Ecology Handbook: A Restorationists' Guide to Reference Ecosystems. Journal of Environmental Management.

[17] Fogerty, J.E. (2001) Oral History: A Guide to Its Creation and Use. In: Egan, D. and Howell, E.A., Eds., The Historical Ecology Handbook: A Restorationist's Guide to Reference Ecosystems, Oxford University Press, Washington DC, 101-120.

[18] Duvail, S. and Hamerlynck, O. (2007) The Rufiji River Flood: Plague or Blessing? International Journal of Biometeorology, 52, 33-42. http://dx.doi.org/10.1007/s00484-007-0105-8

[19] Ramsar Convention Secreatariat (2002) Tanzania Designates Rich New Ramsar Site. http://www.ramsar.org/cda/en/ramsar-news-archives-2002-ramsar-bulletin-22689/main/ramsar/1-26-45-87^226894000 $\underline{0}$

[20] Starkey, M., Birnie, N., Cameron, A., Daffa, R.A., Haddelsey, L., Hood, L., Johnson, N., Kapapa, L., Makoti, J., Mwangomo, E., Rainey, H. and Robinson, W. (2002) The Kilombero Valley Wildlife Project: An Ecological and Social Survey in the Kilombero Valley, Tanzania. Kilombero Valley Wildlife Project, Edinburgh, 104 p.

[21] Baker, N.E. and Baker, E.M. (2002) Important Bird Areas in Tanzania. A First Inventory. Wildlife Society of Tanzania, Dar es Salaam, 302 p.

[22] Kajembe, G.C. (1994) Indigenous Management System as a Basis for Community Forestry in Tanzania. A Case Study for Dodoma Urban and Lushoto Districts. Tropical Resource Management Paper No. 6, Wageningen Agricultural University, Wageningen, $148 \mathrm{p}$.

[23] Bailey, D.K. (1998) Methods of Social Research. The Free Press Collier-MacMillan Publishers, London, 478 p.

[24] Saunders, M., Lewis, P. and Thornhill, A. (2007) Research Methods for Business Students. 4th Edition, FT Prentice Hall, Harlow, 624 p.

[25] McClanahan, T., Davies, J. and Maina, J. (2005) Factors Influencing Resource Users and Managers’ Perceptions towards Marine Protected Area in Kenya. Environmental Conservation, 9, 283-298. 
[26] Lindskog, P. and Tengberg, A. (1994) Land Degradation, Natural Resources and Local Knowledge in the Sahel Zone of Burkina Faso. GeoJournal, 33, 365-375.

[27] Shibia, M.G. (2010) Determinants of Altitudes and Perception on the Resource Use and Management of Marsabit National Reserve, Kenya. Journal of Human Ecology, 30, 55-62.

[28] Shrestha, R.K. and Alavalapati, J.R.R. (2006) Linking Conservation and Development: An Analysis of Local People’s Altitude towards Koshi Tappu Wildlife, Reserve, Nepal. Environment, Development and Sustainability, 8, 69-84. http://dx.doi.org/10.1007/s10668-005-0188-5

[29] MNRT (2009) Kilombero Valley Ramsar Site Project. Final Report, Ministry of Natural Resources and Tourism, Ifakara, 209 p.

[30] Baker, N.E. and Baker, E.M. (2002) Important Bird Areas in Tanzania. A First Inventory. Wildlife Society of Tanzania, Dar es Salaam, 302 p. 
Scientific Research Publishing (SCIRP) is one of the largest Open Access journal publishers. It is currently publishing more than 200 open access, online, peer-reviewed journals covering a wide range of academic disciplines. SCIRP serves the worldwide academic communities and contributes to the progress and application of science with its publication.

Other selected journals from SCIRP are listed as below. Submit your manuscript to us via either submit@scirp.org or Online Submission Portal.
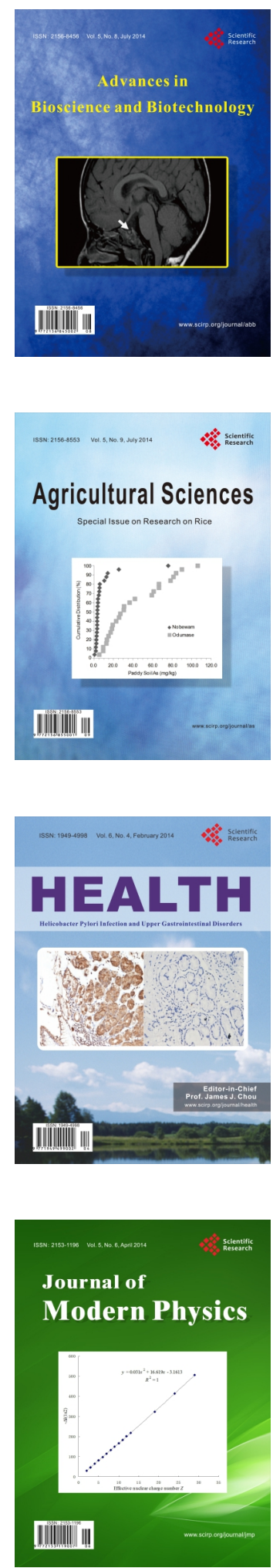
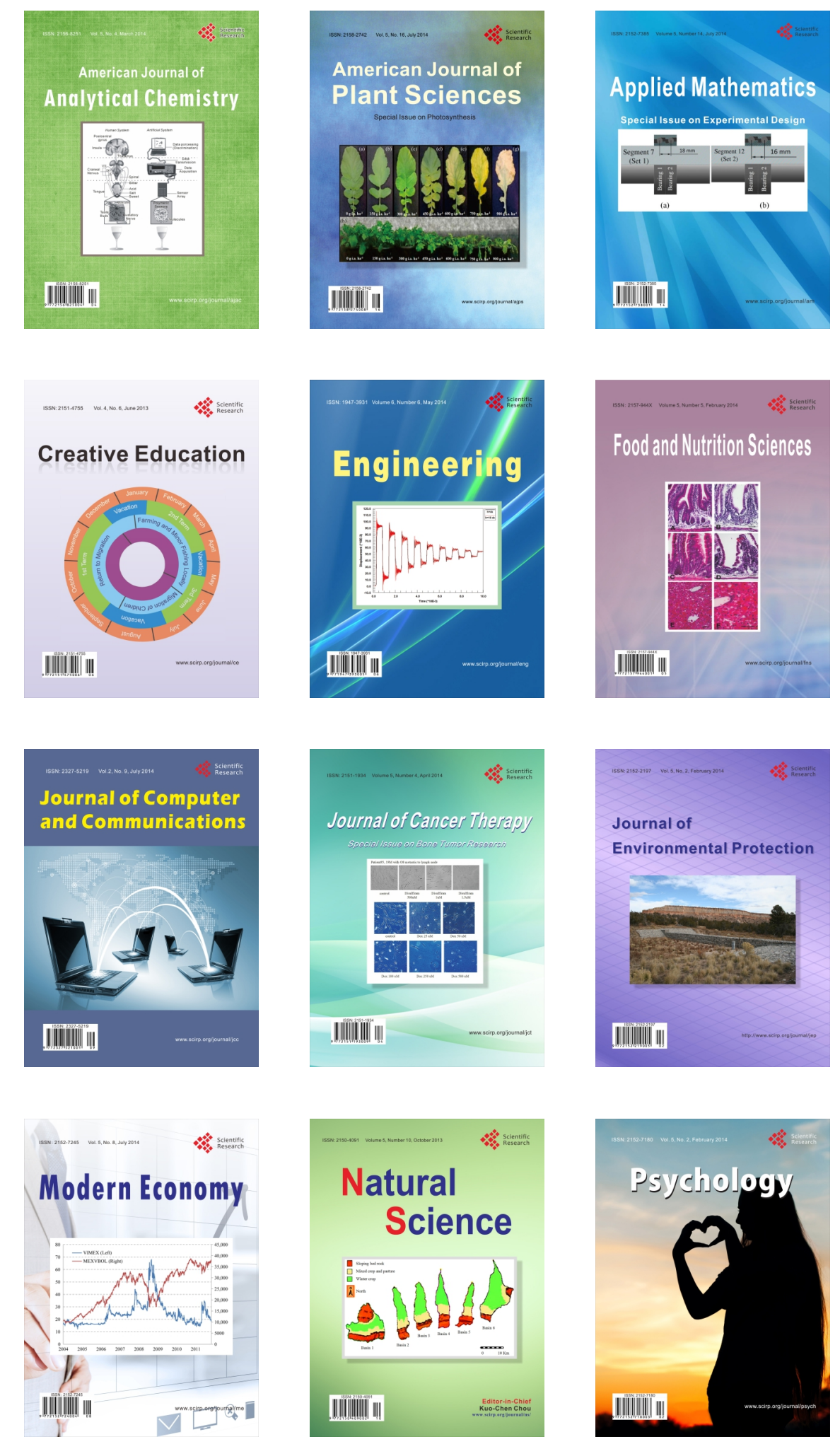